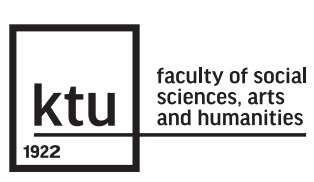

SAL 38/2021

Research Journal Studies about Languages pp. 29-42

ISSN 1648-2824 (print)

ISSN 2029-7203 (online)

DOI 10.5755/j01.sal.1.38.28068
TRANSLATION / VERTIMAS

At the Top of the Tree? Surveying Conference Interpreters as an Elite

Received $11 / 2020 \quad$ Accepted 04/2021

HOW TO CITE: Hoyte-West, A. (2021). At the top of the tree? Surveying conference interpreters as an elite. Studies about Languages / Kalbų studijos 38 , 29-42. http://doi.org/10.5755/j01.sal.1.38.28068

\title{
At the Top of the Tree? Surveying Conference Interpreters as an Elite
}

\author{
Geriausi iš geriausių? Konferencijų vertëjų kaip elito analizė
}

\author{
ANTONY HOYTE-WEST, Independent scholar, United Kingdom
}

\begin{abstract}
In spite of the crucial role that conference interpreters play in the world of international affairs and diplomacy, the concept of conference interpreters as an elite has not attracted significant academic interest to date. Building on the author's previous work (Hoyte-West, 2021), which examined the historical and theoretical aspects of the intersection between conference interpreting and elite sociology, this article reports on the findings of an empirical study with practising conference interpreters. Given increasing interest in sociological aspects of the translational professions, this study is both necessary and timely. In terms of data gathering, snowball sampling was used to disseminate an internet-based survey among professional conference interpreters, with the aim of determining whether conference interpreters viewed themselves as members of an elite. The internet-based survey received 120 responses from freelance, staff, and retired conference interpreters. Using an overwhelmingly quantitative approach, the data was analysed and tabulated, before being subsequently discussed and compared with Khan's (2012) framework of elite resource areas (political, economic, cultural, social network, and knowledge-based), which had previously been applied to the professional sphere of conference interpreting by the author. As such, it was noted that conference interpreters generally did not view themselves as members of an elite; however, further qualitative research in this area remains both desirable and necessary.
\end{abstract}

KEYWORDS: conference interpreters, elite sociology, translation sociology, professional status, quantitative methods, survey-based methods.

Introduction

In a world of international summits and multilateral conferences, conference interpreters play a vital role in facilitating multilingual communication at the highest levels. However, the intersection between conference interpreters and the global political and economic elite remains a neglected area of academic research. In conducting empirical research on conference interpreters' self-evaluation as members of an elite, this study aims to provide an insight into the current context surrounding the conference interpreting profession. This builds directly on the author's previous work (Hoyte-West, 2021), which applied Khan's (2012) framework of elite resources areas to the domain of conference interpreting, and provided a comprehensive historical and theoretical justification for conference interpreters to be consid- 
ered an elite in sociological terms. Accordingly, this current work aims to test this premise through the design and implementation of a survey based on Khan's (2012) framework, which was circulated among practising conference interpreters. The aim of this study, therefore, is to examine whether conference interpreters view themselves as an elite.

\section{Examining \\ Status \\ within the \\ Translational \\ Professions}

In his ground-breaking article outlining Translation Studies as a discipline, Holmes (1988 [1975]) locates a future sociology of translation in the function-oriented focus of Descriptive Translation Studies. In examining translation within a given sociocultural context, this notion anticipated the wider sociological turn in Translation Studies, which has been developed further by a number of leading scholars (for example, see Gouanvic (2002), Chesterman (2006), Gambier (2006), Wolf (2010a, 2010b), Angelelli (2014), and others). Indeed, growing theoretical interest in translation sociology has been mirrored over the past decade by rising empirical interest in the wider translational professions, including - as foreshadowed by Gambier (2007), and Chesterman (2009) - a focus on translators and interpreters as practitioners.

At the global level, large-scale studies examining status within the translational professions have been conducted. Building on general overviews (such as, for example, Gouadec (2007)), these studies include Pym, Grin, Sfreddo, and Chan's (2012) project, which explored the status of the translation profession in several European countries as well as in the United States, Canada, and Australia; in Asia, Chan and Liu (2013) performed a wide-ranging survey-based study examining translator status and the translation market in ten ASEAN member states. Moving to case studies of specific nations, further work has also been conducted in Denmark, where Dam and Zethsen (2008, 2009, 2010, 2011) have examined the domestic translation profession in great detail, and have also published on Danish translators and conference interpreters working for the EU institutions (Dam \& Zethsen, 2013, 2014). Additional research on the status of translators has also been performed in a range of other countries across the globe, including Malaysia (Myoung \& Shunmugam, 2014), Israel (Sela-Sheffy, 2016), Finland (Ruokonen \& Mäkisalo 2018), Turkey (Yılmaz-Gümüş 2018), Iran (Kafi et al., 2018), and recently in Vietnam (Hoang, 2020). In addition, joint studies exploring the professional status of both translators and interpreters have been conducted in Colombia (Quiroz Herrera et al., 2013) and Zimbabwe (Ndlovu, 2020). Indeed, the conclusions drawn by many of these studies illustrate that the occupational status of translators generally remains low to middling in most countries.

However, turning to conference interpreting, the notion of lowly status was not borne out by Gentile (2013) in her worldwide survey-based study of the profession. In examining practitioners' self-perception, she noted that conference interpreters viewed themselves to be of a similar occupational status to members of long-established professions such as lawyers, university professors, and medical doctors; in other words, as "highly-skilled and high-status professionals" (Gentile, 2013, p. 85). This too, aligns with the literature-based findings outlined in Hoyte-West (2021), which evaluated the historical and contemporary development of the conference interpreting profession alongside Khan's (2012) framework of elite resource areas.

\section{Conference} Interpreting: An Overview of the Profession
Given that the author's previous work (Hoyte-West, 2021) justified good grounds for considering conference interpreters as an elite in sociological terms, this section aims to synthesise and summarise the main points covered from both a historical and a contemporary standpoint.

It is worth noting that, although consecutive interpretation had long been a mainstay of international affairs, it was not until the Nuremberg Trials (1945-1946) that conference interpretation finally came into its own. Technological advances meant that real-time simultaneous interpretation in four languages (English, French, German, and Russian) could now take place. Without the luxury of previous formal training, though, those first conference interpreters were a motley crew of seasoned linguists, cosmopolitan polyglots, and regular bilinguals who had undergone a gruelling recruitment process and a short, highly intensive "up-or-out" preparation programme. Nonetheless, the successful implementation of simultaneous interpretation at Nuremberg led to its selection as the standard interpreting format 
of the newly-created United Nations in 1946. There too, a select few of the numerous applicants were chosen to become the first UN interpreters. This was in spite of the lack of official training programmes, as well as the challenge of selecting simultaneous interpreters skilled not only in European languages, but also in Mandarin Chinese (Baigorri-Jalón, 2004).

For understandable reasons, the proceedings at Nuremberg were the object of global attention, and this prominence also extended to include public interest in the interpreters there and later, at the UN. In addition to the exclusive international arenas that those first practitioners were working in, this interest was also highlighted by the exceptional difficulty of the task and the low success rate of various international recruitment processes. In fact, media coverage of those early conference interpreters focused on their exceptional intellectual and linguistic talents, which lead to the myth that fewer than 200 people worldwide were capable of simultaneous interpreting (Baigorri-Jalón, 2004). Of those first interpreters, many held advanced degrees and had acquired their linguistic skills due to the considerable socio-political and economic changes that the early twentieth century had wrought, with many having an émigré background (Gaiba, 1998). The growing prominence of simultaneous interpreters also led to calls for greater professionalisation, which was formalised by the creation of AllC, the International Association of Conference Interpreters, in 1953. With strict membership criteria, AllC remains the only international association representing and advocating the needs of conference interpreters, and also provides guidelines and best practice standards for the profession as a whole (AllC, 2020).

A key development in the conference interpreting profession was the foundation of what is now the European Union in 1957. With the concepts of linguistic equality enshrined from its outset, successive enlargements have increased the number of official languages from four to twenty-four, with a corresponding impact on the interpretation provision required. By way of example, the European Commission's Directorate General for Interpretation (DG Interpretation) assigns interpreters for around 10,000 meetings per year (European Commission, 2018). As such, the enormous demand for interpretation services occasioned by the EU, the UN, and other international institutions over the past seven decades has also led to the development of widespread academic training programmes for budding simultaneous interpreters both in Europe and beyond. Many of these training courses are supported by the aforementioned international institutions (European Commission, 2020; United Nations Language Careers, 2020). However, graduates of such programmes are still required to pass a rigorous accreditation test before becoming freelance or staff interpreters at these institutions. These tests often have a low success rate (Ruiz Rosendo \& Diur, 2017). Therefore, despite advances in interpreter education and training, as well as an increase in the absolute number of professional conference interpreters, the difficulty and exclusivity of the work performed means that it can be argued that the general image of conference interpreters as an elite is still commonplace. As also noted in Hoyte-West (2021), this concept was best encapsulated by a text formerly available on AllC's website, which noted that conference interpreters "represent the elite among a multitude of interpreters who apply their skills in many different areas" (AllC, 2013).

Conference

Interpreting and Elite Sociology

As noted in the introduction to this article, the intersection of conference interpretation and the elite remains understudied. This paucity of scholarly interest can also be extended to the domain of elite sociology in general, as noted for example, by Parsons (1961) and Khan (2012). Indeed, as noted by the latter, the notion of defining an elite remains problematic. For the purposes of this study, however, the definition and framework posited by Khan (2012) has been chosen. Building on previous approaches - including, for example, Mills' (1956) concept of the "power elite", Khan defines the elite as those with "vastly disproportionate control over or access to a resource [that has] transferable value" (Khan, 2012, p. 362). In addition, Khan identified five resource areas used by the elite to promulgate their success: political resources, economic resources, cultural resources, social resources (with particular focus on networking), and knowledge-related resources. Khan notes these resource areas are interlinked with three institutions which propagate the elite's influence: clubs, families, and educational institutions (Khan, 2012).

In applying Khan's resource areas and institutions to the conference interpreting profession, the first resource area - that of political resources - bears little influence. As outlined in the AllC Code of Professional Ethics, conference interpreters must adhere to a strict code of conduct, and thus must not use their position to political ends (AllC, 2018). With regard to economic resources, conference interpreters can receive significant renumer- 
ation, especially when compared to community interpreters (Moody, 2011). By way of example, a 2014 document notes that freelance conference interpreters working on a short-term basis for the UN system could receive up to $738 \mathrm{CHF}$ (over 600 EUR) for a day's work (United Nations System, 2014). In terms of both cultural resources and social resources, the conference interpreting profession has undergone significant changes in its composition since the days of Nuremberg. Though the early conference interpreters came from a range of cultural and linguistic backgrounds, they were largely indistinguishable in their social origins from the majority of conference delegates, and, as Baigorri-Jalón (2004) notes, the profession has become more homogenous over time. Regarding knowledge-related resources, the key discriminator of the conference interpreting profession is the ability to master simultaneous interpretation, a skill that was certainly protectively guarded (Baigorri-Jalón, 2004).

In terms of the three institutions that Khan (2012) cites as ways in which the elite propagate their influence, the first is family. Though many conference interpreters acquired their linguistic and intercultural skills through multilingual upbringings, dynasties of interpreters remain very much the exception (for example, the Kaminker family (AIIC, 2019)), rather than the rule. With regard to Khan's notion of clubs, it can be argued that this is closely linked to the cultural and social resource areas mentioned above. Given the key role played by AllC within the profession, it can be argued it performs this role, promoting cohesion and the creation of an elite composed of those conference interpreters who fulfil its exacting membership criteria. As such, the organisation offers not only professional benefits, but also aspirational prestige as a kitemark of excellence. And finally, the role of educational institutions remains crucial for conference interpreters. As a comparatively young profession, the first institutions to produce trained conference interpreters (for example, ESIT in Paris and FTI in Geneva) remain among the most prestigious, even though training programmes are now offered by many universities around the world. In addition, despite greater uptake of theoretical and research-based models over the last few years, many of the most prestigious conference interpreter training departments at universities are still descended from the master-apprentice approach, which prized the acquisition of the relevant practical skills (Pöchhacker, 2010). In addition to focusing on this development of professional skills - often with a "sink or swim" attitude (Gile, 2005) - it could also be argued that the whole aspect of training hones the "guild-like" (Tiselius, 2009) nature of the conference interpreting profession.

\section{Research \\ Question and Methodology}

As summarised in the previous section, and building on the author's previous conclusions (Hoyte-West, 2021), the analysis of historical and contemporary aspects of the conference interpreting profession has shown that there are good grounds to view conference interpreters as an elite. Accordingly, it was decided to conduct an experimental study based on the following research question: Do conference interpreters view themselves as an elite?

In a similar vein to previous survey-based studies focusing on the translation and interpreting professions (for example, Gentile, 2013; Dam \& Zethsen, 2013; Hoang, 2020), it was decided to conduct empirical research using an online questionnaire. Hence, a survey was created which comprised 15 compulsory closed-answer questions. The questions covered issues uncovered in the literature review, and corresponded broadly with the areas of elite activity outlined by Khan (2012). The survey was accessible for a two-week period, and the internet link to the questionnaire was distributed to contacts within the conference interpreting profession. These included staff interpreters at the European Commission's DG Interpretation, freelance conference interpreters working regularly for the European institutions, and freelance conference interpreters working on the private market. In line with the technique of snowball sampling, the accompanying e-mail also included a statement encouraging participants to forward the link to other conference interpreters, with the aim of reaching the maximum possible audience. In addition, a link to the survey was posted on the forum page of DG Interpretation's internal intranet, $\mathrm{SClCnet}$. Also, the link was forwarded to the head of AllC in the United Kingdom and Ireland, who kindly disseminated the information among its membership. In ethical terms, and in line with best practice across the social sciences (Kelley et al., 2003), the anonymity of participants was also guaranteed. This is especially important given that some of the participants in the research study were members of professional organisations or were working for international institutions.

In order to gain data that could be measured clearly, the questions were primarily closed-answer in format. The Likert scale was also widely used; eight of the questions asked participants to agree or disagree using the following five-point gradation: (yes, strongly agree; yes, somewhat agree; neither agree nor disagree; no, somewhat 
disagree; no, strongly disagree). The advantage here was that data could be easily captured and quantified, as well as permitting data analysis to be carried out by using the rudimentary statistical calculations of the mean and standard deviation. Due to the relatively straightforward nature of these calculations, it also meant that there was no need to carry out complex correlation or regression analyses. Consequently, it was possible to capture, analyse, and present the findings without using sophisticated statistical analysis software such as SPSS or Stata.

There were a number of logistical benefits to using an internet-based questionnaire. In addition, to transcending geographical boundaries and allowing as many potential participants as possible to be reached, the questionnaire could also be accessed at any time. Notwithstanding these positive aspects, however, there were some potential disadvantages. As Bryman (2012) states, there can be issues in ensuring the quality of the sample. With an internet-based questionnaire, there is an inability to verify the identity of the participant and thus the veracity of any information supplied. As a result, precautionary measures were implemented. It was decided not to publish the link to the survey on publicly accessible social media channels such as the Facebook or Twitter pages of the European Commission's DG Interpretation or AllC. Instead, it was decided to rely on known sources in the profession to distribute the link. The rationale behind this approach aimed to ensure that those with access to the survey, and by extension, those participating in it, would be conference interpreters. Thus, the risk of the merely 'curious' completing the survey was minimised greatly, and the corresponding risk of fraudulent answers was diminished. This approach, whilst perhaps leading to a lower number of responses than if the survey had been made more widely available, nonetheless aimed to ensure the quality of the data produced.

Regarding other issues that needed to be considered in the preparation and implementation of the survey, it was decided not to define key terms such as "elite" and "economic clout". Rather, the onus was placed on the participant to determine their own definition and perception of these expressions within the context of the survey. Despite the fact that this could be said to be influenced by an interpretivist approach, this decision was made in order to minimise any element of bias on the part of the researcher. Although, as Bryman (2012) and O'Leary (2012) both highlight, all research projects are subject to some element of subjectivity, whether through choice of topic, methodology, or theoretical framework, the author was keenly aware of particular influence regarding this particular research topic.

Finally, linguistic considerations also needed to be accounted for. The survey was conducted in English, the researcher's native language, and, as de Swaan (2001, p. 17) states, one of the world's "supercentral" languages, in that it acts as a lingua franca. It is also one of the European Union's 24 official languages, and one of the six working languages of the United Nations. Although the European Commission conducts its day-to-day business in three working languages (English, French, and German), the dominance of English in the European sphere is already well-attested in the wider literature, as Philippson (2003) confirms. Furthermore, given that the target group of the survey was conference interpreters, it can be thus surmised that potential participants would have at least some level of proficiency in English, even if it were not part of their official language combination.

A total of 120 respondents took part in the survey, with 99 participants completing all 15 comResults pulsory questions. 22 respondents also chose to answer the optional final question. Of the participants, $38.33 \%$ were freelance or self-employed interpreters working primarily for a national or international organisation, and thus comprised the largest group. At $30.83 \%$, staff interpreters at national or international institutions also represented a substantial minority. Freelance conference interpreters working primarily on the private market and also on an ad hoc basis were also represented, as were a small number of former or retired conference interpreters (4.17\%). As a result, given the different professional spheres of the conference interpreters polled, it can be said that a multiplicity of views across the sector was successfully obtained. In asking directly whether conference interpreters viewed themselves as part of an elite, a Likert scale was used to obtain the necessary data. As illustrated in Fig. 1, 40.83\% of the respondents held no particular preference; this can be compared with $30.83 \%$ who answered in the affirmative, and $28.33 \%$ who held the opposite opinion. This distribution is centred around a mean score of 3.1, with the corresponding standard deviation of 1.1 demonstrating that the results are reasonably tightly dispersed with few answers at either end of the spectrum. 
As a conference interpreter, do you consider yourself part of an elite?

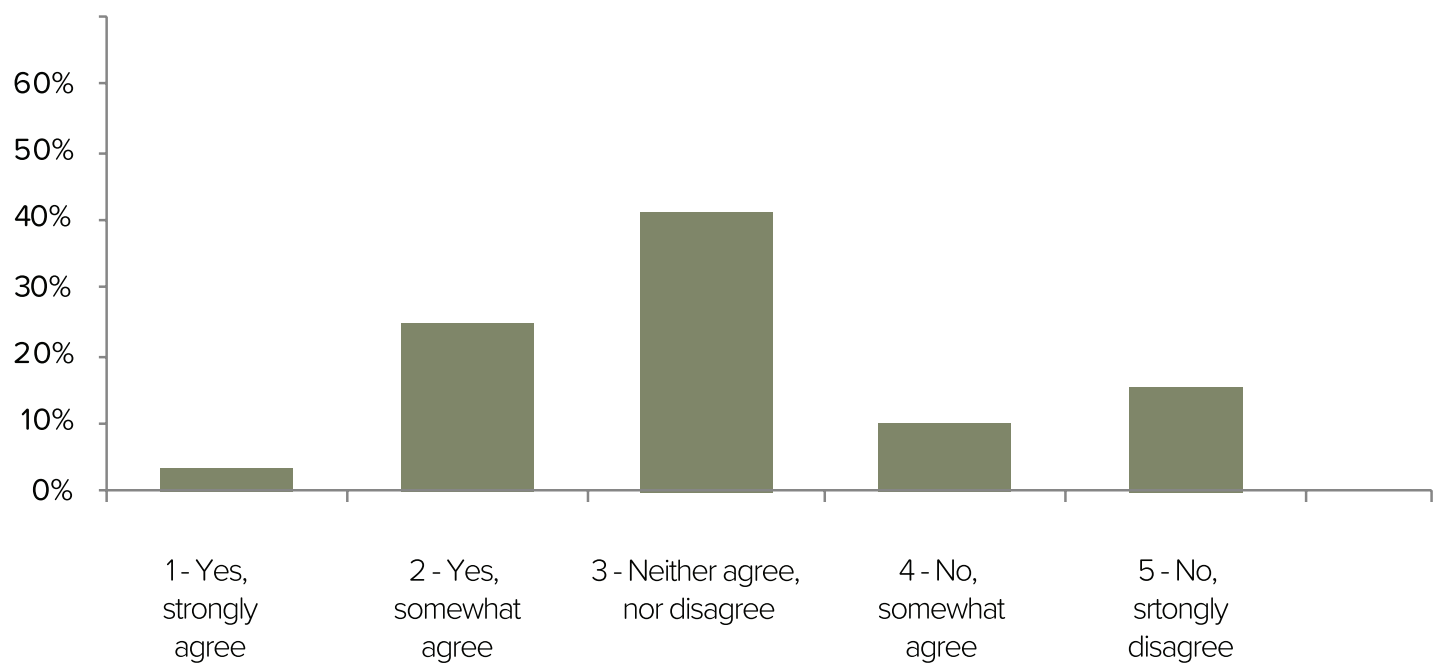

Fig. 1 Participants' self-evaluation as members of an elite

Has the prestige of the interpreter training programme you attended been of importance to your career as a conference interpreter?

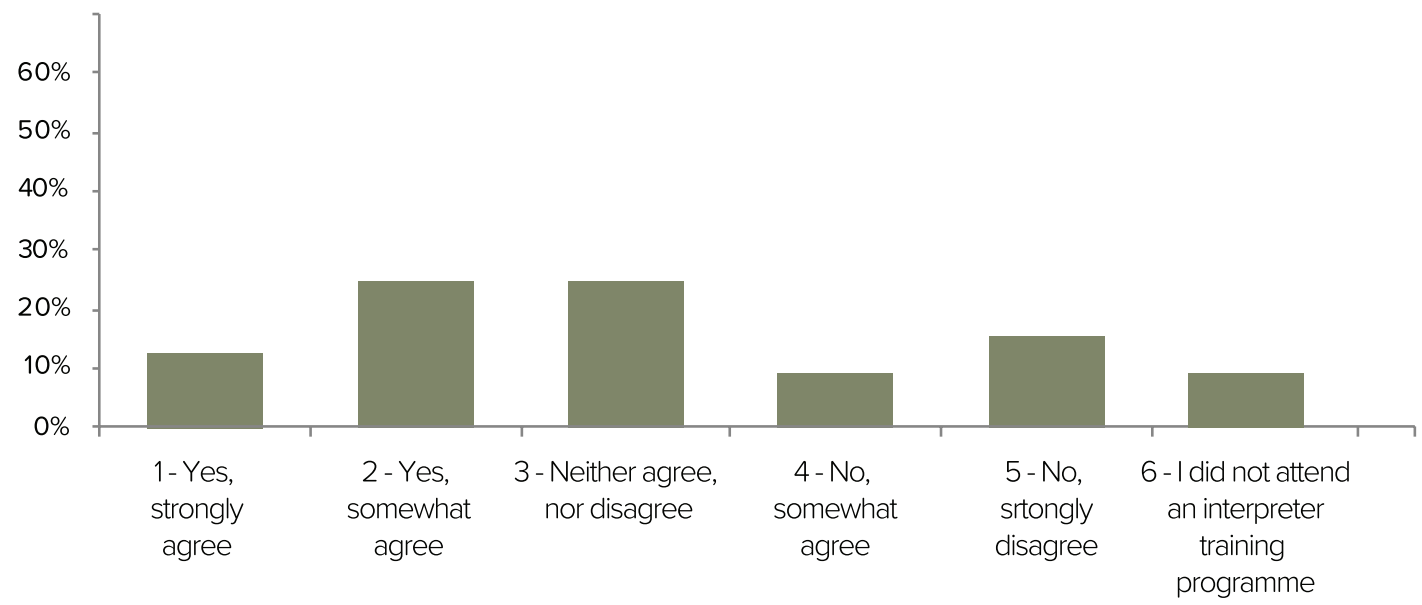

Fig. 2 Prestige of the interpreter training programme attended

In addition, a significant majority of survey participants (65.44\%) stated that they did not consider themselves elite compared to other language professionals; just over a third (34.45\%) declared that they did. Of the participants who answered in the affirmative, 88\% viewed themselves as elite compared to language teachers in secondary schools; by way of contrast, less than a third (32\%) considered themselves to be elite in comparison with court interpreters.

Moving to the elite resource areas posited by Khan (2012), information about the education and training of the survey participants was then obtained. The findings showed that a clear majority (73.28\%) had followed a postgraduate course in interpreting, with much smaller minorities holding an undergraduate-level qualification in the subject, or having followed on the job training. In seeking further details as to whether the prestige of the interpreter training programme they attended had borne any impact on participants' professional career (Fig. 2), 
$26.72 \%$ felt that the training programme had neither been of importance or unimportance to their career; however, $25.86 \%$ felt that it had been of some importance. $7.7 \%$ stated that they had not attended a relevant training programme, and those data were discounted from the statistical analysis. As such, the mean of 2.8 shows a learning towards a positive view, but this is countered by a standard deviation of 1.3 , demonstrating that the results are reasonably widely dispersed.

In comparing themselves to freelance or staff interpreter colleagues based on the conference interpreting training programmes that they had attended, more than three-quarters $(78.45 \%)$ stated that they would not consider themselves elite compared to any or their freelance or staff conference interpreter peers. However, $11.21 \%$ did note that they would consider themselves elite compared to a freelance or self-employed interpreter who did not attend the same training programme as the participant.

Moving to political influence, participants were asked if they felt that they had direct political influence. Using a Likert scale, $86.21 \%$ answered in the negative, including $68.97 \%$ who strongly disagreed. The consistency of these results is illustrated by the high mean of 4.5 , and the low standard deviation of 0.8 . This indicates that the results are unequivocal. In asking for further clarification as to whether participants felt that their day-to-day work in the booth led to direct political influence, once again, the responses were overwhelmingly negative. As such, $75.65 \%$ disagreed with the consistency of results demonstrated by the mean of 4.5 and the standard deviation of 1.0.

In exploring conference interpreters' economic clout, a question was posed as whether participants felt that their salary offered them economic influence. Of the answers received (Fig. 3), 42.16\% neither agreed nor disagreed; $26.48 \%$ responded negatively, whereas $31.37 \%$ agreed. Despite the mean of 3.0, the diversity of these results is reflected in the standard deviation of 1.1, which illustrates a reasonably wide dispersal of the data.

As a conference interpreter, do you believe that your salary gives you economic clout?

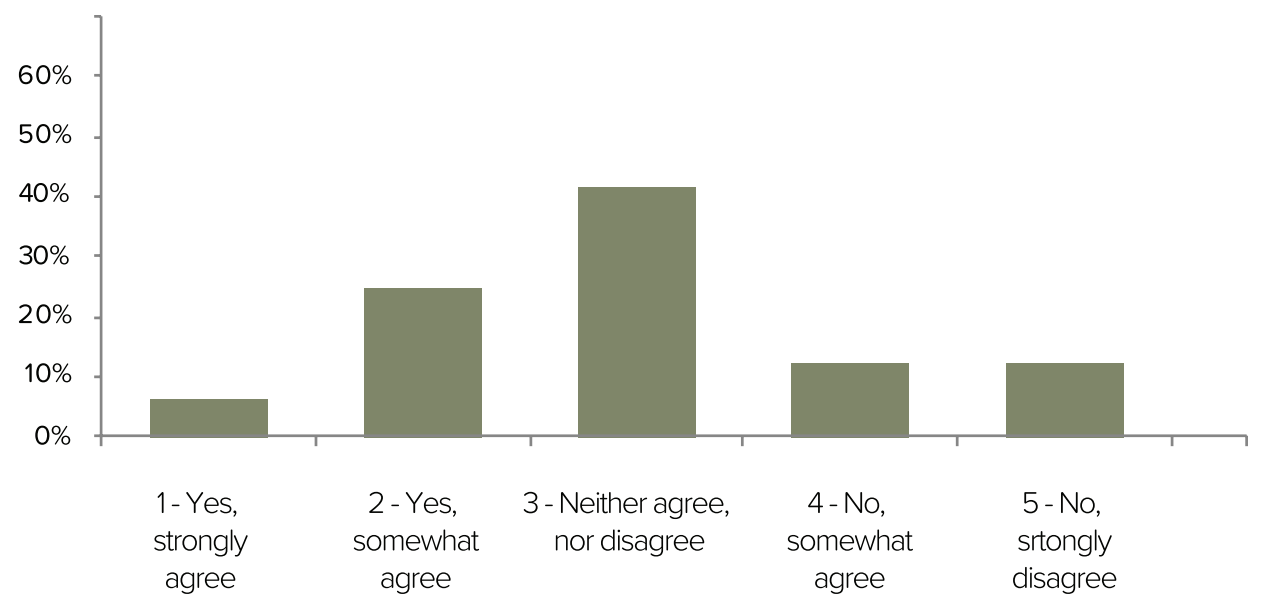

Fig. 3 Salary and perceived economic clout

Participants were subsequently asked to rate the economic clout of different types of conference interpreters by giving them a score out of 5 . In this instance, 1 represented a low level of economic influence, whereas 5 demonstrated a high grade of economic clout. As illustrated in Fig. 4, the results illustrate some disparity between the different groups.

With a mean of 3.6, staff interpreters [blue] were considered on average to be the best performers. However, as Fig. 4 highlights, although $40 \%$ of participants graded them as possessing the highest level of economic clout, $18 \%$ felt that staff interpreters in fact had the lowest level of economic influence (the highest for any type). This is supported by the standard deviation of 1.5, which illustrates that the results are quite widely dispersed. As Fig. 4 illustrates, no other type of conference interpreter has such an uneven profile. 


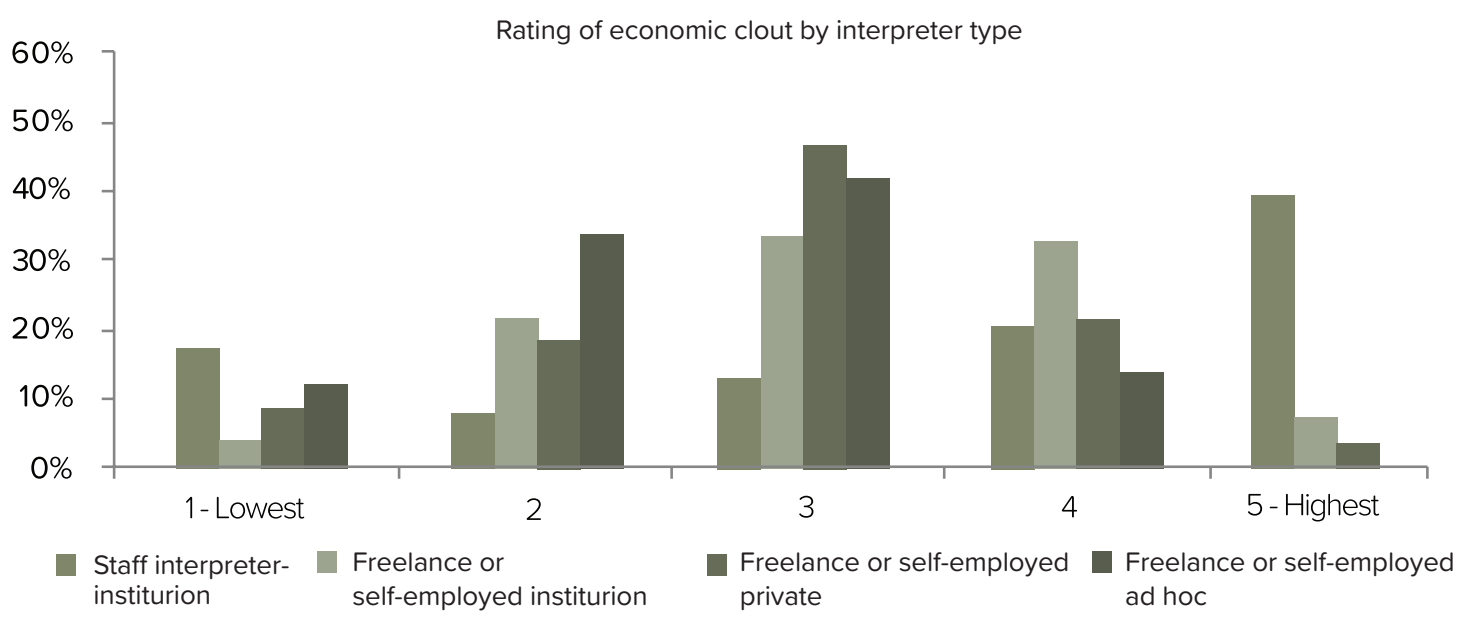

Fig. 4 Rating of economic clout by interpreter type

The data reported for the other three groups were more consistent. With a mean of 3.2, freelance or self-employed interpreters working primarily for national or international institutions were the second-highest; the standard deviation of 1.0 also demonstrates the consistency of these results. Freelance or self-employed interpreters working primarily on the private market were scored at a mean of 3.0. Combined with a standard deviation of 0.9 , this illustrates that these results are also considered consistent. Conference interpreters working on an ad hoc basis received the lowest rating, with a mean of 2.6. Here, the standard deviation of 0.7 serves to highlight the homogeneity of these results.

Turning to Khan's notion of the social network, participants were then asked to self-evaluate regarding the strength of their social network. $53.46 \%$ of respondents felt that they did have a strong social network, as opposed to $20.79 \%$ who disagreed. With a mean of 2.6 , the general trend was to support this view. Combined with a standard deviation of 1.1, these results can be said to be relatively widely dispersed across the different categories. This was followed by asking respondents whether they felt they had a strong social network compared to other types of conference interpreter. $82 \%$ of them noted that they did not feel that their personal social network carried more weight than that of their colleagues.

In moving to unique attributes, respondents were then asked if they viewed themselves as elite because of their unique professional skill: the ability to interpret in simultaneous mode. $42.57 \%$ agreed and $36.63 \%$ disagreed. The remaining $20.79 \%$ neither agreed nor disagreed. Correspondingly, the mean of 3.1 had an accompanying standard deviation of 1.5, demonstrating that the results were evenly scattered across the range of answers (Fig. 5).

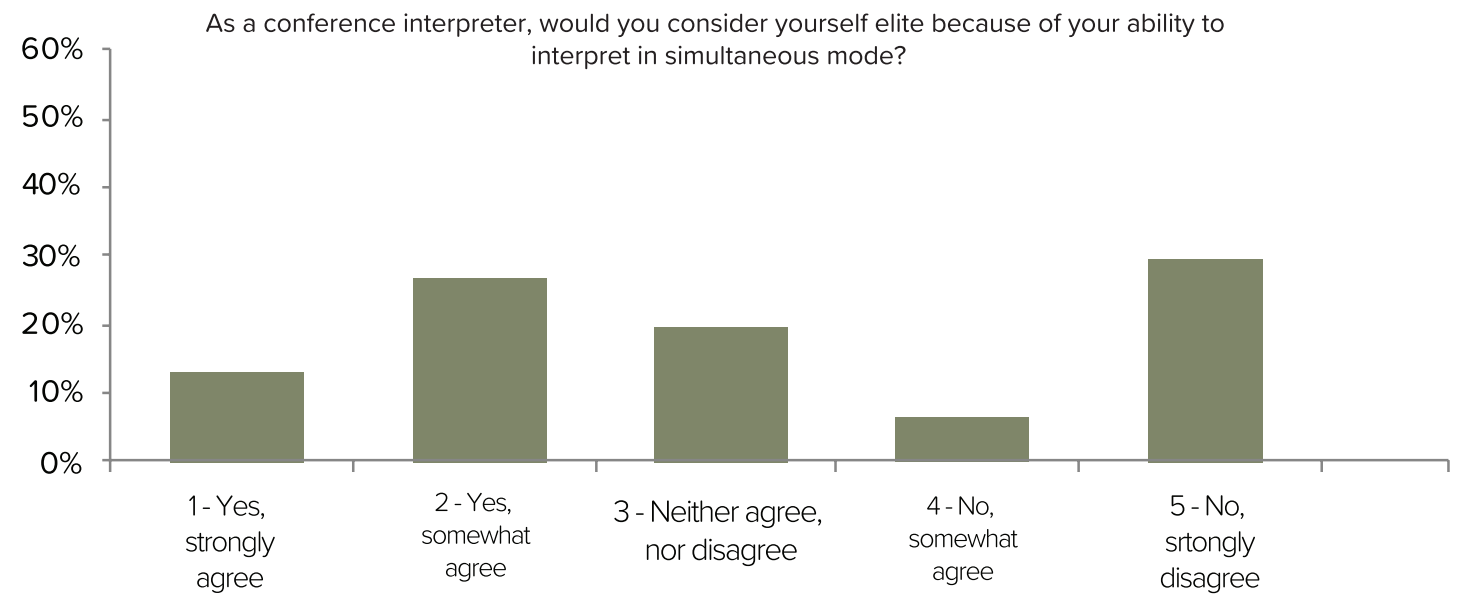

Fig. 5 Elite status on the basis of ability to interpret simultaneously 
In enquiring about the role of the respondents' upbringing in their professional career as a conference interpreter, $56.56 \%$ of those polled felt that the way they were raised had influenced their future career, although $26.26 \%$ disagreed. The mean of 2.6 was combined with a standard deviation of 1.5, demonstrating that the data are fairly widely dispersed. And finally, information was also sought about the importance of professional organisations to the participant's career as a conference interpreter. $49.49 \%$ disagreed that such organisations had had any bearing, whereas $36.36 \%$ answered in the affirmative. The mean score of 3.4 was accompanied by a standard deviation of 1.4, illustrating the diversity of responses and their relatively wide dispersal.

The final, optional question in the survey consisted of a text box where respondents could input comments and observations that they felt to be relevant. 24 participants chose to add further information, and each of these responses was assigned a letter from $A$ until $X$. The responses varied in their nature and tone. Respondents $F$ and $V$ both openly questioned the purpose and usefulness of the research study. Participants $R$ and $U$ reported that the survey questions were somewhat strange. Respondents $\mathrm{K}$, $\mathrm{L}$, and $\mathrm{U}$ also felt that the questionnaire seemed to be in favour of the approach of viewing conference interpreters as an elite. Two participants $(N, T)$ wrote that they felt ill at ease when completing the survey, thus offering a wider illustration of what Bryman (2012, p. 271) terms "question threat." This can be defined as where a participant does not wish to answer a particular question in the survey, for whatever reason, and as a result does not proceed any further. Several respondents also noted that that no clear definition was offered for an elite (K, V, W), nor for economic clout $(\mathrm{N}, \mathrm{T}, \mathrm{V})$. Participants $\mathrm{D}$ and $Q$ also stated that a definition for an 'ad hoc' basis should have been provided, as did respondent $\mathrm{S}$. In addition, participants $D$ and $Q$ both believed that there should have been an additional category in the survey's opening question to include freelance interpreters who work for many international organisations.

Several comments focused on participants' personal opinions of the elite. Respondents $\mathrm{G}$ and $\mathrm{S}$ both viewed it negatively, with $\mathrm{G}$ reporting that the concept of elite as applied to interpreting was "repugnant." Respondent E noted that conference interpreters can be extremely elitist, although views were felt to be changing. Respondent $\mathrm{M}$ also felt that this elitism no longer delineated the conference interpreting profession. Participant $\mathrm{S}$ concurred, stating the "era of interpreting divas is over." Respondent $\mathrm{K}$ also highlighted negative aspects of the profession, namely the lack of social and ethnic diversity, as well as attitudes towards different language combinations and to other types of interpreters.

Participant A noted that staff interpreters did not necessarily have more influence than other types of interpreters because of their professional status; rather, personal attributes take precedence. Respondent $G$ also highlighted the need for a combination of particular personal and professional skills. In terms of status, participants $L$ and $T$ reported that interpreting was no different to any other job. Participant $X$ highlighted that, although their personal view was that it was a job like any other, it was acknowledged that non-interpreters view interpreting as something extraordinary.

Participant $\mathrm{B}$ cited that economic clout is market-dependent. Respondents $\mathrm{H}$ and $\mathrm{T}$ stated that additional factors, such as quality, age, seniority, and language combination, also influence an interpreter's level of economic influence. Regarding the importance of the training programme attended, participant $O$ stated that although it does carry some weight, it was the day-to-day work that was more crucial. Respondent W highlighted their opinion that interpreting was a skill that "everyone could learn", and noted that the training course they attended had influenced that approach.

Discussion terms conference interpreters are somewhat non-aligned in their self-perception as an elite, and generally do not class themselves as being more prestigious than other linguistic professionals. This notion was supported by some of the comments submitted. Respondent $\mathrm{G}$ noted that conference interpreters and court interpreters perform different jobs and have different requirements, an argument that Participant $T$ stated was also true of other language professionals. Respondent $X$ also reported that the wider perception of the profession made it somehow remarkable. Thus, it can be also argued that this perception is externally rather than internally constructed.

The vast majority of survey respondents (86\%) overwhelmingly disagreed that their profession endowed them with direct political influence. This concords with the information cited in the literature review (AllC 2018) which stated that conference interpreters should not participate as political actors under any circumstances. When asked if their work in the interpreting booth led to any direct political influence, $76 \%$ disagreed with that asser- 
tion. This was somewhat surprising, given that that more than two-thirds of those polled (69\%) were either staff interpreters or freelance conference interpreters working primarily for national or international institutions. It is thus to be expected, that conference interpreters working in such environments would frequently be required to interpret keynote speeches and political conferences. Nonetheless, the statistical significance of these data highlights the importance of the strong ethical framework that underpins the profession. This view is supported by respondent $\mathrm{R}$, who writes that "the questions about political influence gave me a feeling they were formulated by someone who has no clue what an interpreter is or does."

The perceived economic clout of conference interpreters received reasonably widely dispersed results. When asked if conference interpreters possess economic influence, $42 \%$ indicated that they neither agreed nor disagreed, and slightly under a third (31\%) answered in the affirmative. When asked to provide further information regarding the economic clout of various types of interpreters, staff interpreters had the highest aggregate score, despite there also being a considerable number of low-ranking grades. The comments varied widely on this aspect, with participant $X$ acknowledging that interpreting was well-paid. Other respondents, though, noted that there was a multiplicity of other factors that led to financial influence, including language combination and the demands of the market, rather than simply working as either a staff interpreter or a freelance conference interpreter. These findings can be viewed as surprising given the evidence outlined in the literature review, which illustrated the considerable earning potential accorded to conference interpreters. However, it is important to state that everything is comparative, hence the wide dispersal of results.

As noted in the literature review, cultural aspects of the conference interpreting profession are strongly linked with resources based on the social network. When polled, just over half $(53 \%)$ of those participating agreed that they had a strong social network, and the overwhelming majority felt that their social network was no stronger than that of other types of interpreter. At first glance, it could be argued that these figures support the cohesiveness of the profession. However, input from the comments section provided additional insights. Participants $\mathrm{E}$ and $\mathrm{M}$ both noted that the profession was in a state of change, although respondent $\mathrm{K}$ did state than in terms of social composition, the profession has remained extremely homogenous. Whereas participant $\mathrm{G}$ highlighted the importance of both personal and professional skills, respondent A stated that "it all depends on personal factors (who you are rather than what you are, and what you can do with it/ get out of it)." Thus, it can be stated that although conference interpreting appears to still be a cohesive profession, nonetheless, there is a meritocratic rather than a strictly hierarchical approach.

Regarding the ability to interpret in simultaneous mode, which, as stated previously, is the core professional skill of conference interpreting, $42.5 \%$ agreed that this skill made them elite. This can be compared to $21 \%$ who held neutral views, and $36.5 \%$ who disagreed outright. Participant W noted that it was "hilarious" to think that elite status could be attained through the acquisition of a skill that "everybody could learn." This is somewhat surprising, as it might have been expected that conference interpreters would promote their unique ability more vociferously. This is especially notable given the above-mentioned fact that together with the commonplace use of multiple passive languages, it is one of the key discriminators between conference interpreting and other forms of interpretation.

Focusing on the three institutional aspects that Khan (2012) delineates in his study, over half (57\%) of respondents felt that their upbringing had made an impact on their future career as a conference interpreter. However, the data were widely dispersed, with more than a quarter (26\%) disagreeing. Unfortunately, there were no comments pertaining to this aspect of the survey, so there were no opportunities for triangulation. In focussing on what Khan (2012) terms "clubs", the importance of professional conference interpreting organisations was also assessed. As stated in the literature review, the role of these organisations is key not only to the creation of an elite, but also to wider notions of common professional identity and culture. The responses produced data that were widely dispersed. Just under half (49\%) affirmed that these organisations had been beneficial, whereas just over a third (36\%) stated the reverse. In particular, the comment from participant G stated that AllC was "seriously overestimating its value and influence" and that the organisation needed to adapt to the changing circumstances. As outlined previously, AllC and other professional conference interpreting associations do play a gate-keeping role; however, the diversity of responses received regarding this issue shows how polemical it has the potential to be.

The role of educational institutions was also surveyed. Participants were invited firstly to state the method in which they had become a conference interpreter. Subsequently, they were asked if the prestige of the training 
programme attended had had any influence on their career. Finally, they were asked to compare how they viewed themselves compared to different types of conference interpreter who had completed the same or different training programme. Almost three-quarters of respondents $(73 \%)$ had taken a postgraduate MA or diploma in interpreting studies. As to whether the prestige of the programme had provided a lasting effect on their career, the data was fairly evenly spread, with $41 \%$ affirming that it had. However, more than three-quarters (78\%) of those polled stated that they did not feel that the training programme they had attended led them to view themselves as an elite compared to other conference interpreters. This aspect of the study attracted two comments. Participant $O$ outlined that the prestige of the interpreting school attended is secondary to the professional abilities of the interpreter. Respondent $W$ stated that the training programme attended was important in their overall perception of the profession. Given the information outlined in the literature review, the findings are somewhat surprising, given widespread anecdotal information attesting to the importance of specific interpreter training institutions to the profession; however, from the data obtained, this does not appear to be conclusive in this instance.

\section{Concluding} Remarks

Further to the analysis of the data using the theoretical approach outlined by Khan (2012) the results illustrate that there are good grounds to state in general terms that conference interpreters do not view themselves as an elite. As noted in the previous section, except for the strongly negative response to the questions asking if conference interpreters were a political elite, the data relevant to other elite resources were usually widely dispersed, with no strong positive or negative response. Although a majority of respondents agreed that they did possess a strong social network, and that their professional skill was a key differential, nonetheless the cumulative responses were not overwhelmingly affirmative. The same was true of the question regarding the role of upbringing. For the other domains of elite activity (economic, educational, and organisational), however, the responses were very mixed, leading to results being fairly widely scattered across the spectrum. In terms of possessing a strong social network (and by extension, cultural influence), attaching a premium to their professional skill, and believing their upbringing to be important to their career, the findings revealed that participants believed all of these factors to be relevant in this case. Therefore, the claims made in the literature review were supported by the experimental findings. The overwhelming majority of responses focussing on conference interpreters' political influence were negative, again confirming the assertions made in the literature review regarding this topic. However, the analyses of the findings regarding the economic and educational influence, together with the importance of the professional organisation, were all somewhat mixed. There was an overwhelming preference for neutral results. The data were fairly widely dispersed across the spectrum. As a result, the findings did not display strong positive or negative responses. Accordingly, it was very difficult to make generic statements and to create judgments based on the data, simply due to their wide dispersal. However, given that only four out of the eight elite areas denoted by Khan (2012) have been fulfilled, it can be stated in general terms that conference interpreters do not view themselves as an elite.

The study also uncovered a number of areas for further research. Given the spread of results gleaned through the quantitative data from the questionnaire, it was acknowledged that the comments written by participants provided additional qualitative insight. It was noted, therefore, that future projects could include greater use of qualitative research methods, including interviews, focus groups, and even case studies of individual conference interpreters. In addition, possibilities for comparative research with community and court interpreters could also provide valuable information regarding notions of elite status between and within other forms of interpreting.

At this juncture, it is worth noting that the current study was conceived and executed before the COVID-19 pandemic, which has affected the global conference interpreting profession significantly (Shaw 2020). With many summits and conferences moved online, many conference interpreters have had to use remote simultaneous interpreting. Even before the coronavirus restrictions, the uptake of such technologies was described as "the biggest paradigm shift in professional interpreting since Nuremberg" (Jiménez Serrano, 2019, p. 60). Consequently, the COVID-19 crisis has meant that the usage of remote simultaneous interpreting formats has understandably exploded in popularity. Though the impact of these technological advances on the profession remains to be seen, it is clear that these developments portend profound changes for the world of conference interpreting. As such, it is likely that there will be continued interest regarding the intersection between conference interpreters and the elite, with corresponding implications for the profession and the self-image of its practitioners. 
References

1 AllC. (2013). AllC Conference Interpreters are professionals who translate orally from and into over 60 languages. http://aiic.net/ [Accessed July 10, 2013]

2 AllC. (2018). Code of Professional Ethics. https://aiic.org/document/6299/Code\%20 of\%20professional\%20ethics_ENG.pdf

3 AllC. (2019). Family memories - Lest we forget (Round table of 1 Oct. 2019). https://aiic. ch/press/family-memories-lest-we-forget/

4 AllC. (2020). AllC at a glance. https://aiic.org/ site/world/about/aiicataglance

5 Angelelli, C. V. (ed.). (2014). The Sociological Turn in Translation and Interpreting Studies. Amsterdam: John Benjamins Publishing Company. https://doi.org/10.1075/bct.66

6 Baigorri-Jalón, J. (2004). Interpreters at the United Nations: A History. Salamanca: Ediciones Universidad Salamanca.

7 Bryman, A. (2012). Social Research Methods. Oxford and New York: Oxford University Press.

8 Chan, A. L. J. \& Liu, C. F. M. (2013). The translator status, the translation market and developing economies: A preliminary study of ASEAN countries. Southern African Linguistics and Applied Language Studies, 31(4), 435-450. https://doi.org/10.2989/16073614. 2013.86444

9 Chesterman, A. (2006). Questions in the sociology of translation. In Duarte J., F., Assis Rosa A., \& Seruya T. (eds). Translation Studies at the Interface of Disciplines (pp. 9-27). Amsterdam: John Benjamins Publishing Company.

10 Chesterman, A. (2009). The Name and Nature of Translator Studies. Hermes - Journal of Language and Communication Studies, $42,13-29$

11 Dam, H.V. \& Zethsen, K.K. (2008). Translator Status. A Study of Danish Company Translators. The Trans/ator, 14 (1), 71-96. https://doi. org/10.1080/13556509.2008.10799250

12 Dam, H. V. \& Zethsen, K. K. (2009). Who Said Low Status? A Study on Factors Affecting the Perception of Translator Status. JoSTrans: The Journal of Specialised Translation, 12, 2-36.

13 Dam, H. V. \& Zethsen, K. K. (2010). Translator Status: Helpers and Opponents in the Ongoing Battle of an Emerging Profession. Target. International Journal of Translation Studies 22(2), 194-211. https://doi.org/10.1075/target.22.2.02dam

14 Dam, H. V. \& Zethsen, K. K. (2011). The Status of Professional Business Translators on the Danish Market: A Comparative Study of Company, Agency and Freelance Translators. Meta 56(4), 976-997. https://doi. org/10.7202/1011263ar

15 Dam, H.V., and Zethsen, K.K. (2013). Conference Interpreters - the Stars of the Translation Profession?: A Study of the Occupational Status of Danish EU Interpreters as Compared to Danish EU Translators. Interpreting 15(2), 229-259. https://doi.org/10.1075/ intp.15.2.04dam

16 Dam, H.V. \& Zethsen, K.K. (2014). Translators in International Organizations: A special breed of high-status professionals? Danish EU translators as a case in point. In Angelelli, C. (ed.) The Sociological Turn in Translation and Interpreting Studies (pp. 93-113). Amsterdam: John Benjamins Publishing Company.

17 European Commission (2018). 2018 Annual Activity Report. DG Interpretation. https:// ec.europa.eu/info/sites/info/files/scic_ aar_2018_final.pdf

18 European Commission (2020). Knowledge Centre on Interpretation: Universities. https://ec.europa.eu/education/knowledge-centre-interpretation/universities_en

19 Gaiba, F. (1998). The Origins of Simultaneous Interpretation: The Nuremberg Trial. Ottawa: University of Ottawa Press.

20 Gambier, Y. (2006). Pour une socio-traduction. In Duarte J, F., Assis Rosa A., \& Seruya T. (eds). Translation Studies at the Interface of Disciplines (pp. 29-42). Amsterdam: John Benjamins Publishing Company.

21 Gambier, Y. (2007). Y at-il place pour une socio-traductologie?. In Wolf M., \& Fukari, A. (eds). Constructing of Sociology of Translation (pp. 205-217). Amsterdam: John Benjamins Publishing Company.

22 Gentile, P. (2013). The Status of Conference Interpreters: A Global Survey into the Profession. Rivista internazionale di tecnica della traduzione - International Journal of Translation 15, 63-82.

23 Gile, D. (2005). Teaching Conference Interpreting: A Contribution. In Tennant, M. (ed). Training for the New Millennium: Pedagogies for Translation and Interpreting. Amsterdam/Philadelphia: John Benjamins Publishing Company, pp. 127-151. https://doi. org/10.1075/btl.60.12gil 
24 Gouadec, D. (2007). Translation as a Profession. Amsterdam: John Benjamins Publishing Company.

25 Gouanvic, J.-M. (2002). A model of structuralist constructivism in Translation Studies. In Hermans, T. (ed.) Cross-cultural transgressions. Research models in Translation Studies. (pp. 93-102). Manchester: St Jerome.

26 Hoang, L. B. (2020). Translation Profession Status in Vietnam: Document and Empirical Analyses. Transletters. International Journal of Translation and Interpreting, 3, pp. 99-123.

27 Holmes, J. (1988) [1975]. The Name and Nature of Translation Studies. In Holmes, J. (ed). Translated! Papers on Literary Translation and Translation Studies (pp. 66-80). Amsterdam: Rodopi.

28 Hoyte-West, A. (2021, in press). In a league of their own? Conference interpreters viewed through the prism of elite sociology. In Djovčoš, M., Kusá, M., and Perez, E. (eds.) Translation, Interpreting, Culture: Old Dogmas, New Approaches (pp. 101-116). Berlin: Peter Lang.

29 Jiménez Serrano, Ó. (2019). Foto fija de la interpretación simultánea remota al inicio del 2020. Revista Tradumàtica: Tecnologies de la Traducció, 17, 59-80. https://doi. org/10.5565/rev/tradumatica.239

30 Kafi, M., Khoshsaligheh, M., \& Hashemi, M. R. (2018). Translation profession in Iran: Current challenges and future prospects. The Translator, 24(1), 89-103. https://doi.org/10.1080/135 56509.2017 .1297693

31 Kelley, K., Clark, B., Brown, V., \& Sitzia, J. (2003). Good practice in the conduct and reporting of survey research. International Journal for Quality in Health Care, 15(3), 261-266. https://doi.org/10.1093/intqhc/mzg031

32 Khan, S. R. (2012). The Sociology of Elites. Annual Review of Sociology, 38, 361-377. https:// doi.org/10.1146/annurev-soc-071811-145542

33 Mills, C. W. (1956). The Power Elite. London, Oxford, \& New York: Oxford University Press.

34 Moody, B. (2011). What is a Faithful Interpretation? Journal of Interpretation, 21(1), 38-51.

35 Myoung, S.K., \& Shunmugam, K. (2014). The Translation Profession in Malaysia: The Translator's Status and Self-Perception. GEMA Online Journal of Language Studies, 14(3), 191-205. https://doi.org/10.17576/ GEMA-2014-1403-12
36 Ndlovu, E. (2020). Interpretation and Translation as Disciplines and Professions in Zimbabwe: A Critical Appraisal. Language Matters, 51(2), 129-147. https://doi.org/10.1080/10 228195.2020.1773518

37 O'Leary, Z. (2010). The Essential Guide to Doing Your Research Project. London: Sage Publications.

38 Parsons, T. (1961). Stratification and Mobility. In Parsons, T., Shils, E., Naegele, K.D., and Pitts, J. R. (eds.) Theories of Society: Foundations of Modern Sociological Theory, Vol. I. New York, Free Press of Glencoe, pp. 517-518.

39 Philippson, R. (2003). English Only Europe? Challenging Language Policy. London: Routledge.

40 Pöchhacker, F. (2010). The role of research in interpreter education. Trans/ation \& Interpreting, 2(1), 1-10.

41 Pym, A., Grin, F., Sfreddo, C., \& Chan, A. L. J. (2012). The Status of the Translation Profession in the European Union. Luxembourg: Publications Office of the European Union.

42 Quiroz Herrera, G., Gómez Hernández, N.D., \& Zuluaga Molina, J. F. (2013). Panorama general del traductor e intérprete oficial en Colombia. Núcleo 30, 165-203.

43 Ruiz Rosendo, L., \& Diur, M. (2017). Admission exams in international organisations: The United Nations' Language Competitive Examination (LCE). CLINA: An Interdisciplinary Journal of Trans/ation, Interpreting and Intercultural Communication, 3 (2), 33-52. https://doi.org/10.14201/clina2017323352

44 Ruokonen, M., \& Mäkisalo, J. (2018). Middling-Status Profession, High-Status Work: Finnish Translators' Status Perceptions in the Light of Their Backgrounds, Working Conditions and Job Satisfaction. Trans/ation and Interpreting, 10 (1), 1-17. https://doi. org/10.12807/ti.110201.2018.a01

45 Sela-Sheffy, R. (2016). Elite and Non-elite Translator Manpower: The Non-Professionalised Culture in the Translation Field in Israel. The Journal of Specialised Translation 25, 54-73.

46 Shaw, C. (2020). Interpreting in the Face of a Pandemic. The ATA Chronicle, 49 (3), 30-31.

47 de Swaan, A. (2001). Words of the World: The Global Language System. Cambridge \& Malden, MA: Polity Press.

48 Tiselius, E. (2009). A Sociological Perspective on Expertise in Conference Interpreting. In Azadibougar, O. (ed.), Translation Effects: 
Selected Papers of the CETRA Research Seminar in Translation Studies 2009. https:// www.arts.kuleuven.be/cetra/papers/files/elisabet-tiselius-a-sociologicalperspective-on.pdf

49 United Nations Language Careers. (2020). MoU network. https://languagecareers.un. org/dgacm/Langs.nsf/xpONetwork.xsp

50 United Nations System. (2014). Revised rates for short-term conference interpreters, effective 1 January 2014. https://www.unsystem.org/content/2014-interpreters-rates

51 Wolf, M. (2010a). Sociology of Translation. In
Gambier, Y. \& van Doorslaer, L. (eds.). Handbook of Translation Studies (pp. 337-343). Amsterdam: John Benjamins Publishing Company.

52 Wolf, M. (2010b). Translation 'going social'? Challenges to the (Ivory) Tower of Babel. MonTI. Monografías de traducción e interpretación, 2, 29-46. https://doi.org/10.6035/ MonTI.2010.2.2

53 Yılmaz-Gümüş, V. (2018). Solidity and Professionalization of Translation: Turkey as a Case in Point. HERMES - Journal of Language and Communication in Business, 58, 43-63.

\section{Santrauka}

\section{Antony Hoyte-West. Geriausi iš geriausių? Konferencijų vertèjų kaip elito analizè}

Nepaisant esminio vaidmens, kuri konferencijų vertėjai atlieka tarptautinių santykių ir diplomatijos pasaulyje, konferencijų vertèjų kaip elito samprata iki šiol nesulaukẻ reikšmingo akademinio dèmesio. Remiantis ankstesniais autoriaus darbais (Hoyte-West, 2021) kurie nagrinejjo sąsajos tarp konferencijų vertimo ir elito sociologijos istorinius ir teorinius aspektus, šis straipsnis pristato empirinio tyrimo, atlikto su praktikuojančiais konferencijų vertejjais, išvadas. Atsižvelgiant ị augantị susidomèjimą sociologiniais vertimo profesijų aspektais, šis tyrimas yra būtinas ir savalaikis. Duomenų surinkimui buvo naudojamas sniego gniūžtės atrankos metodas, išplatinant internetinès apklausos anketą tarp profesionalių konferencijų vertejjų ir siekiant ¡vertinti, ar konferencijų vertejjai priskiria save elito sluoksniui. Internetinejje apklausoje dalyvavo 120 laisvai samdomų, pagal darbo sutartị dirbančių bei profesinę karjerą jau baigusių konferencijų vertèjų. Duomenys pirmiausia buvo analizuojami ir susisteminti naudojant kiekybini metodą, o vèliau aptarti bei palyginti su Khan'o (2012) elito samprata (politinis, ekonominis, kultūros, socialinių tinklų bei žinių elitas), kuria buvo remiamasi ir paties autoriaus profesinèje konferencijų vertimo veikloje. Pastebèta, jog konferencijų vertejjai paprastai nepriskiria savęs elito sluoksniui. Vis dèlto, tolesnis kokybinis šios srities tyrimas yra reikalingas ir pageidautinas.

\section{About the Author}

\section{ANTONY HOYTE-WEST}

Independent scholar, United Kingdom

\section{Research interests}

Institutional translation and interpreting, the professional status of translators and conference interpreters, multilingualism and language policy

E-mail antony.hoyte.west@gmail.com

ORCID iD 0000-0003-4410-6520 